Skin Cancer Vol. 20 No. 22005

基底細胞癌

\title{
当科における基底細胞癌の統計的検討
}

\author{
南 祥一郎 伊藤 孝明 中川 登 松本 晴子 \\ 小倉 千香 林 義明 \\ 兵庫医科大学皮庙科学教室
}

\begin{abstract}
要旨 1985 年から 2002 年までの 18 年間に, 当科において病理組織学的に基底細胞癌と診断 した 207 症例，247病変について検討した。男性 123 例，女性 84 例で男性にやや多いが，18年 間で増加, 減少傾向は認めなかった。部位別では, 顔面が $70.4 \%$ と最も多く, 鼻部, 眼瞼部, 煩部で $75 \%$ を占めていた。WHO 分類に準じて病理組織学的分類の再検討を行ったが, nodular type が $37.7 \%$ と最も多く，顔面だけでみるとその比率は $44.9 \%$ に達した。WHO分類 に含まれていない mixed typeが $28.3 \%$ 存在し，これらの取り扱いを含め，病理組織学的分類 の確立が重要であると思われる。
\end{abstract}

\section{Statistical Analysis of Basal Cell Carcinoma}

Shoichiro MINAMI, Takaaki ITO, Noboru NAKAGAWA, Haruko MATSUMOTO, Chika OGURA, Yoshiaki LIN

Department of Dermatology, Hyogo College of Medicine

In this study, we evaluated 207 patients (123 males and 84 females) with basal cell carcinoma (BCC) who were registered during the past eighteen years (1985-2002) in the department of dermatology, the hospital of Hyogo college of medicine. The diagnosis of $\mathrm{BCC}$ was made, based on histopathology. The incidence of BCC had not changed during the period. In 247 lesions of the cases, BCC was most frequently located on the face (70.4\%), especially on the nose, eyelids and cheeks. The nodular type was most common (37.7\%), and the mixed type was found unexpectedly more frequently (28.3\%). We propose to establish the histological classification of BCC including the mixed type. [Skin Cancer (Japan) $2005 ; 20: 127-131]$

Key words : Basal cell carcinoma, Statistical analysis, Histological classification

\section{はじめに}

基底細胞癌（Basal cell carcinoma以下， BCC）は，最も多い皮膚癌である。その臨床 症状から診断は比較的容易であり，手術治療に より治療成績も良いが, 顔面の正中部に好発す
るため整容面も含め治療に難渋することも多 い。また, 病理組織所見の多彩さから, その分 類が確立されていない現実もある。

今回, 過去 18 年間に当科において病理組織 学的にBCCと診断した症例について, 病理組 織学的分類の再検討を含め統計的検討を行った ので報告する。 


\section{対象と方法}

1985 年から 2002 年までの 18 年間に当科で病 理組織学的にBCC と診断した 207 症例 249 病変 について統計的検討を行った。

基底細胞母斑症候群に生じたもの 1 症例 16 病変, 色素性乾皮症に生じたもの 2 症例 8 病変, 脂腺母斑に発生したもの 5 症例が含まれていた (表 1 )。

\section{表 1 . 対象症例}

\section{- 男性 123症例 女性 84 症例 合計 207 症例 (247病変) \\ - 基底細胞母斑症候群 1 症例 (16病変) \\ - 色素性乾皮症 \\ - 脂腺母斑に生じたもの 5 症例}

\section{1 ) 年次別症例数}

男性 123 症例，女性 84 症例の合計 207 症例に ついて年次別症例数を調べた。複数年にわたり 多発しているものは, 初めに出現した年のみ症 例数として登録した。

\section{2 ) 年齢別症例数}

上記 207 症例につき，年齢別に 10 歳毎に分け 症例数を調べた。

\section{3 ) 部位別の病変数}

多発例もあるため, 207 症例の 247 病変につ いて, 顔面, 頭部, 頸部, 躯幹, 四肢, 腋窩, 陰部に分けて検討した。

また, 顔面の病変に関しては, 眼瞼部, 鼻部, 煩部，耳部，口唇部，下顎部に分けて検討した。

\section{4 ) 大きさ別の病変数}

大きさの確認が正確にできた 190 病変につい て $5 \mathrm{~mm}$ 以下, $6 \sim 10 \mathrm{~mm}, 11 \sim 20 \mathrm{~mm}, 21 \sim$ $30 \mathrm{~mm}, 31 \mathrm{~mm}$ 以上に分けて検討した。大きさ の確認ができなかったものは，主に基底細胞母 斑症候群や色素性乾皮症などに生じた小型の病 変であった。

\section{5 ) 病理組織学的分類}

247 病変にWHO の病理組織学的分類（表 2 ） に準じて検討を行った。

Basal cell carcinoma in basal cell nevus syndrome は 1 症例 16 病変を認めたが, この 16 病 変は各々に合致する他の分類に含めた。

Pigmented typeについては, 分類上今回は除 外した。

また，それぞれの分類の混合型も存在したた め，それらは mixed type として別に分類した。

\section{表 2. 基底細胞癌の病理組織学的分類（WHO 分類）}

- multifocal superficial type

- nodular basal cell carcinoma

- infiltrating basal cell carcinoma

- fibroepithelial basal cell carcinoma

- basal cell carcinoma(BCC) with adnexal differentiation

- basosquamous carcinoma

- keratotic basal cell carcinoma

- pigmented basal cell carcinoma

- basal cell carcinoma in basal cell nevus syndrome

- micronodular basal cell carcinoma

（最新皮席科学大系より引用）

\section{結果}

\section{1 ) 年次別症例数}

図 1 に示すように 1992 年だけ 3 症例と少な くなっているが, 平均 11.5 症例で, 特に増加, 減少傾向は認めなかった。

\section{2 ）年齢別症例数}

図 2 に示すように年齢と共に症例数は増加 し，特に60歳以上に多く認められた。

10歳台に生じたものは, 16 歳女性の色素性 乾皮症の症例の顔面に生じたものと，18歳男 性の下顎部に生じたものであった。

20 歳台に生じたものは，28歳男性の下顎部 に生じたものと, 29 歳男性の大腿部に生じた ものであった。

\section{3 ）部位別の病変数}

表 3 に示すように顔面が 174 病変 $(70.4 \%)$ と最多で，躯幹が 39 病変 $(15.8 \%)$, 頭部が 16 


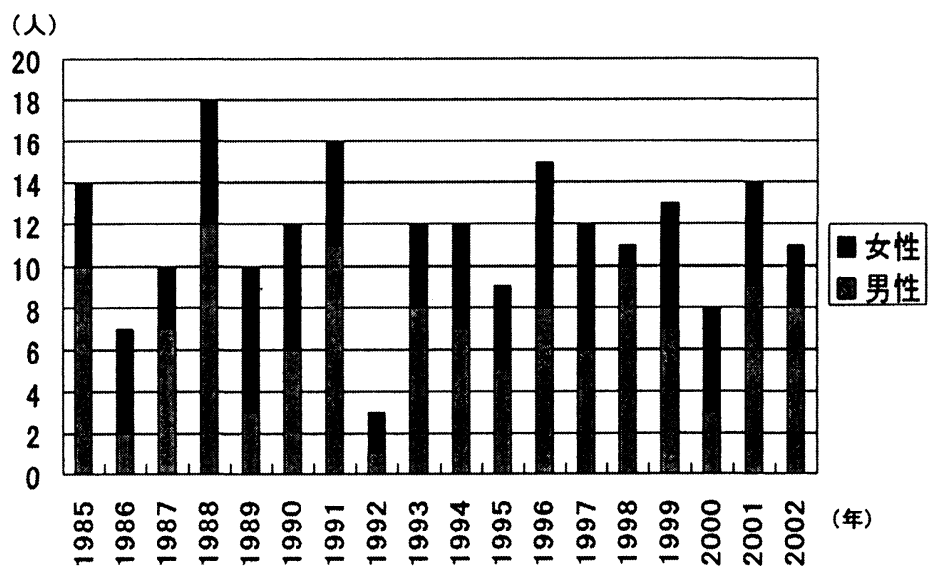

図 1. 当科に扔ける基底細胞癌の年次変化

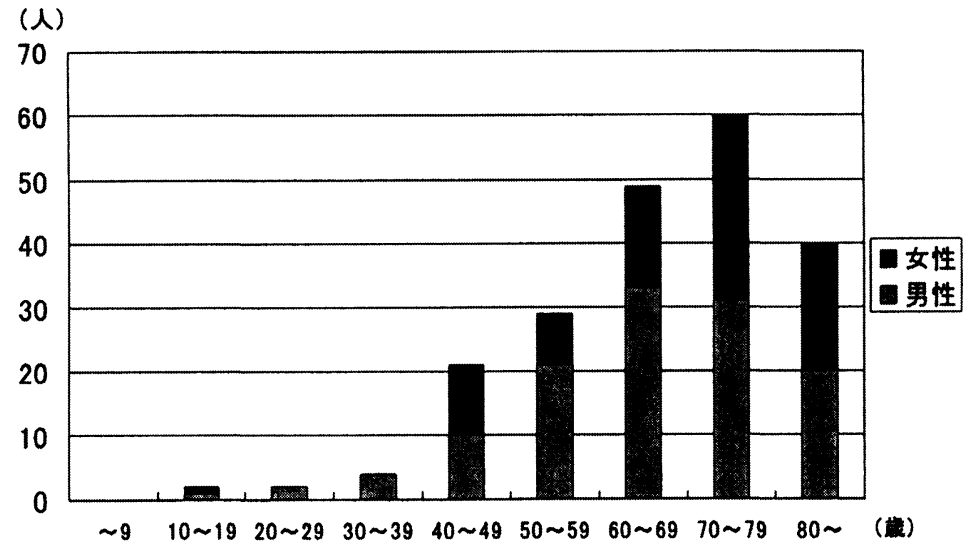

図 2. 当科に扔ける基底細胞癌の年齢別症例数

表 3. 部位別病変数

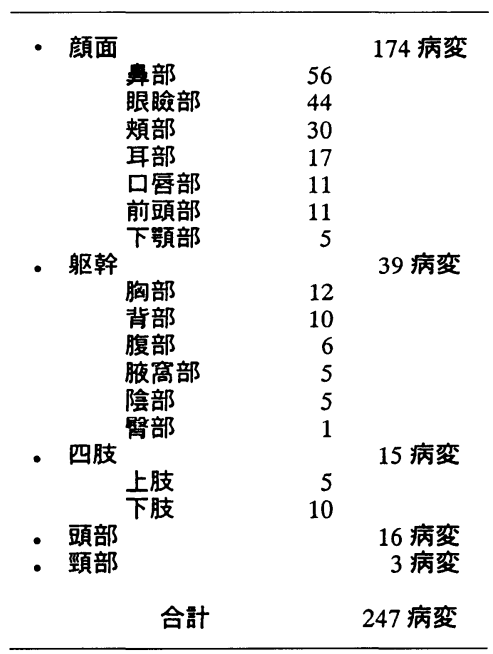

病変 $(6.5 \%)$, 四肢が 15 病変 $(6.1 \%)$, 頸部 3 病変 $(1 \%)$ であった。腋窩, 陰部は躯幹に含 めたが各々 5 病変 $(2 \%)$ であった。

さらに, 顔面の 174 病変について検討した結 果, 鼻部が 56 病変 $(32.2 \%)$ と最も多く, 眼 瞼部が 44 病変 $(25.3 \%)$, 规部 30 病変 $(17.2 \%)$ などが多く認められた。

\section{4 ）大きさ別の病変数}

$5 \mathrm{~mm}$ 以下のものが 30 病変 $(15.8 \%), 5$ $10 \mathrm{~mm}$ 大のものが 63 病変 $(33.2 \%), 11$ $20 \mathrm{~mm}$ 大のものが 65 病変 $(34.2 \%), 21$ $30 \mathrm{~mm}$ 大のものが 19 病変 $(10 \%), 31 \mathrm{~mm}$ 以上 のものが 13 病変 $(6.8 \%)$ であった。 $31 \mathrm{~mm}$ 以 
上のものは躯幹 6 病変, 頭部と陰部がそれぞれ 3 病変であり顔面以外の部分に多く, 最大のも のは腹部の $76 \times 53 \mathrm{~mm}$ 大のものであった。

\section{5 ) 病理組織学的分類}

表 4 に示すように nodular type が93病変 $(37.7 \%)$ と最多で, mixed type 70 病変 (28.3 $\%)$, superficial type 46 病変（18.6\%）などが 多くみられた。Mixed typeの中では nodular-micronodular type が 23 病変 $(32.9 \%)$ で, 全体 に占める割合も $9.3 \%$ と比較的多く認められた。

その他, infiltrating type と micronodular type が 18 病変 $(7.2 \%)$, BCC with adnexal differentiation $か ゙ 1$ 病変, keratotic basal cell carcinomaが 1 病変であった。

顔面の 174 病変において同様の検討を行った が (表 5 ), nodular type が 78 病変 $(44.8 \%)$, mixed type が 48 病変 $(27.6 \%)$ と多く認められ た。 Mixed type の中では nodular-micronodular type が 21 病変 $(12.1 \%)$, nodular-keratotic type が 9 病変 $(5.2 \%)$ 多く認められた。その 他, micronodular type は 18 病変 $(10.3 \%)$, infiltrating type は 16 病変 $(9.2 \%)$, Superficial type は 12 病変 $(6.9 \%)$ であった。

\section{表 4. 病理組織学的分類別の病変数}

\begin{tabular}{|c|c|c|}
\hline nodular type & & 93 病变 \\
\hline superficial type & & 46 病变 \\
\hline infiltraiting type & & 18 病变 \\
\hline micronodular type & & 18 病变 \\
\hline BCC with adnexal differentiation & & 1 病変 \\
\hline keratotic type & & 1 病変 \\
\hline mixed type & & 70 病变 \\
\hline nodular-micronodular type & 23 病変 & \\
\hline nodular-keratotic type & 10 病変 & \\
\hline nodular-infiltraing type & 10 病变 & \\
\hline nodular-superficial type & 7 病変 & \\
\hline \multirow[t]{2}{*}{ others } & 20 病变 & \\
\hline & 合計 & 247 病変 \\
\hline
\end{tabular}

\section{考察}

BCCは，本邦においても症例数が多く，過

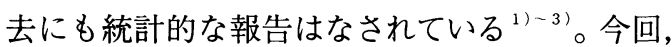
過去 18 年間の当科における BCC の統計的検討 を行ったが，過去の報告と大きく変わるところ はなかった。

年次変化に関しては，1992年だけ 3 症例と 極端に少なくこの原因は分からないが，その他 は特に大きな変化はなく, 増加減少傾向はない ものと思われる。年齢別の症例数に関しては, 年齢と共に増加し，60歳以上に多くなってい る。80歳以上では数的には少なくなっている が，手術症例が少なかっただけで, 発生頻度が 低下しているわけではないと思われる。10歳 台, 20 歳台に生じたものは, 1 症例だけ色素 性乾皮症に生じた症例があったが，その他は特 に基礎疾患，前駆病変を認めていなかった。ま た，結果には示さなかったが基底細胞母斑症候 群や色素性乾皮症以外の症例で複数の病変を生 じたものが 9 症例認められた。部位別には顔面 が約 $70 \%$ と過去の報告と同程度で最も多かっ たが，その中でも鼻部，眼瞼部，煩部が多く， この 3 つで $75 \%$ を占めていた。

今回は，最新皮膚科学大系 ${ }^{4)} に も$ 用いられて いるWHOの BCC の病理組織学的分類に準じて

表 5. 病理組織学的分類別の病変数 (顔面)

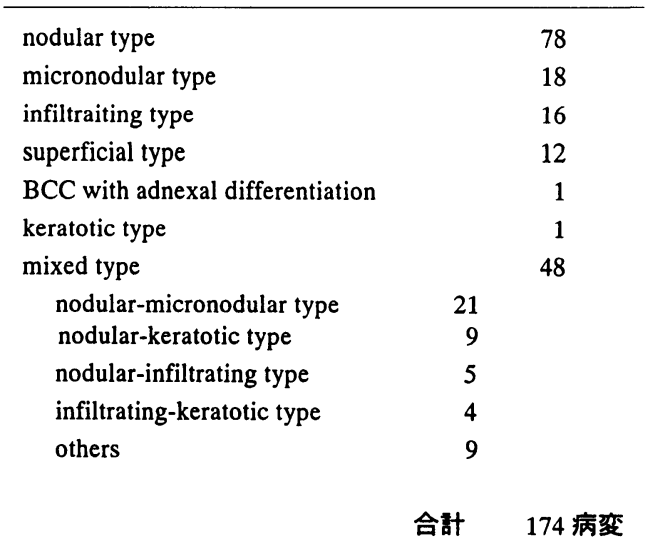


分類を行った。その結果は表 4 に示すとおり， nodular type が93病変 $(37.7 \%)$ と最も多かっ た。部位別で最も多く, 治療上も問題になるこ とが多い顔面においては, 表 5 に示すように 78 病変 $(44.9 \%)$ と nodular typeの占める割合 がさらに高くなる。

今回の検討において注目すべき点は, WHO 分類にはない mixed type が70病変 $(28.3 \%)$ と多く認められたことである。この組織分類に は明確な基準はないが，明らかに一つの組織型 として分類しきれないものが存在することも事 実である。Mixed typeについて言及している 報告 ${ }^{5)}$ においてもその頻度は $21.8 \%$ となってお り，我々の集計と同じ程度である。たた，この 組織分類において問題となるのは標本の作成に 関する点である。当院においてはBCCに対し ては，多くの場合腫瘍の中央部で 1 切片だけを 作成し組織診断を行っている。しかし, 治療上 の目的で多くの切片を作成依頼することがある
が，切片によって組織分類が違うこともある。 つまり，多くの切片を作成し観察しないと，正 確な組織診断がされない可能性があることが今 回の検討において明らかになった。この点を踏 まえて, BCCに対する新たな病理組織学的分 類の確立が望まれるところである。

\section{文献}

1）石原和之：皮周悪性腫瘍. 基底細胞癌一全国アン ケートの集計と説明. Skin Cancer, 9 : 80-83, 1994

2) 石田晋之介, 藤澤崇行, 梁取明彦, 他: 獨協医大 皮覤科に扔ける基底細胞上皮腫の統計.Skin Cancer, $9: 379-383,1994$

3）東野清彦, 相模成一郎: 基底細胞上皮腫の統計的 観察. 皮䖉, $29: 802-804,1987$

4) 小野友道, 萱島研一, 若杉正司: 最新皮唐科学大 系. 12, 玉置邦彦, 第 1 版, 中山書店, 東京, 2002, p82-98

5) Sexton M, Jones DB, Maloney ME : Histologic pattern analysis of basal cell carcinoma. J Am Acad Dermatol, 23 : 1118-1126, 1990 